R.A. Silva, S.R. Teixeira, A.E. Souza, D.I. Santos, M. Romero, J.Ma. Rincón, Nucleation kinetics of crystalline phases from a kaolinitic body used in the processing of red ceramics. Applied Clay Science Volume 52, Issues 1-2, April 2011, Pages 165-170; doi:10.1016/j.clay.2011.02.019

\title{
Nucleation kinetics of crystalline phases from a kaolinitic body used in the processing of red ceramics
}

\author{
R.A. Silva ${ }^{a}$, S.R. Teixeira ${ }^{a}$, , A.E. Souza ${ }^{a}$, D.I. Santos ${ }^{b}$, M. Romero ${ }^{c}$, J.Ma. Rincón ${ }^{c}$ \\ a Departamento de Física, Química e Biologia, Faculdade de Ciências e Tecnologia, \\ Universidade Estadual Paulista — UNESP, 19060-080 Presidente Prudente, SP, Brazil \\ ${ }^{\mathrm{b}}$ Departamento de Física, UNESP, 17033-360 Bauru, SP, Brazil \\ ${ }^{\mathrm{c}}$ Instituto de Ciencias de la Construccíon Eduardo Torroja, CSIC, C/Serrano Galvache 4, 28033 \\ Madrid, Spain
}

\begin{abstract}
The crystallization kinetics of red ceramic raw material from the western part of São Paulo State, Brazil, was examined by differential thermal analysis (DTA) and X-ray diffraction (XRD). The chemical composition of the clay sample was determined by $\mathrm{X}$-ray fluorescence (XRF). Non-isothermal crystallization kinetic methods have been applied to the study of the mechanism of crystallization in this kaolinitic material. The exothermic peak shifted to higher temperatures $\left(945\right.$ to $974{ }^{\circ} \mathrm{C}$ ) with increasing heating rate $\left(10\right.$ to $\left.50{ }^{\circ} \mathrm{C} / \mathrm{min}\right)$. The average activation energies determined by the Kissinger method $(787 \pm 85 \mathrm{~kJ} / \mathrm{mol})$ and the Ligero method $(721 \pm 32 \mathrm{~kJ} / \mathrm{mol})$ are in agreement. The Avrami constant $\mathbf{n}$ obtained by the Ligero method and the $\mathbf{m}$ parameter (Matusita method) values were between 1 and 1.5 , which indicate a three-dimensional crystal growth with polyhedral morphology and surface nucleation as the dominant mechanism. X-ray diffraction data indicate that this activation energy is not associated with the crystallization of mullite. Scanning electron microscopy (SEM) images of fired (1000 and $1190{ }^{\circ} \mathrm{C}$ ) samples show their densification during the sinterization process.
\end{abstract}

\section{Research Highlights}

Kaolinitic clay used by the ceramic industry. Kinetic and mechanism of crystallization using differential thermal analysis (DTA). Spinel phase Al-Si with a structure of short-range order and nucleation of mullite.

\section{Keywords}

Kinetics; Crystallization; Kaolin; Red ceramic; Mullite 


\section{Introduction}

The red ceramic industry fabricates structural ceramic products such as solid bricks, hollow bricks, roof tiles and rustic floor tiles used by the civil construction industry. Usually, these industries use sedimentary clay minerals mixed with other sandy minerals to obtain a paste with the appropriate plasticity for each type of ceramic piece. In general, these structural ceramic products have low added value and are inexpensive compared to other materials used in building construction. Meanwhile, some industries produce this kind of ceramic using white clay material, which could be used to produce other kinds of ceramic pieces with higher added values than red ceramics.

The raw materials used by this industry have a complex chemical composition and consist of natural mixtures of three components according to their grain size: plastic material (clay minerals) and non-plastic materials, called silt (fine particles) and sand (coarse particles). Its mineralogical composition is more complex than traditional porcelain which is a threecomponent body composed of plastic material (clays), fluxing agent (generally feldspar, used to reduce the firing temperature) and quartz. In the red ceramic industry, two or more natural materials are generally mixed to prepare the ceramic body with the desired properties. In some cases, fluxing and/or non-plastic materials (for example, quartz) can be used to improve the industrial process and the final ceramic properties. In the western region of São Paulo state, the clay material has kaolinite as the major mineral component together with mica (Teixeira et al., 2001 and Teixeira et al., 2004). Generally, this material has high plasticity due to its high concentration (> $40 \mathrm{wt} . \%$ ) of clay minerals and organic material. The non-plastic fractions consist mostly of silicates, oxides and hydroxides of: aluminum, iron, titanium, and alkaline earth and alkaline elements.

The synthesis of mullite from kaolinite by conventional sintering has been extensively studied, and there are many publications on this subject. Meanwhile, there are also many discrepancies among the published results principally due to the differences in the chemical composition, grain size distribution and firing process of raw clay materials (Martín-Márquez et al., 2009, Okada, 2008, Percival et al., 1974, Romero et al., 2006, Santos et al., 2006,Torres et al., 2004, Traoré et al., 2006 and Yamuna et al., 2002). Firing ceramic mixtures based on clays whose main clay mineral is kaolinite, in general, encompass the following stages for heating: loss of moisture $\left(\mathrm{T}<100{ }^{\circ} \mathrm{C}\right)$; oxidation of organic matter $\left(\sim 350^{\circ} \mathrm{C}\right)$, and loss of OH-groups (principally from goethite and gibbsite); hydroxyl loss (chemically bonded water) of kaolinite phase at $\sim 500{ }^{\circ} \mathrm{C}$ and subsequent conversion to metakaolinite; metakaolinite decomposition at 
R.A. Silva, S.R. Teixeira, A.E. Souza, D.I. Santos, M. Romero, J.Ma. Rincón, Nucleation kinetics of crystalline phases from a kaolinitic body used in the processing of red ceramics. Applied Clay Science Volume 52, Issues 1-2, April 2011, Pages 165-170; doi:10.1016/j.clay.2011.02.019

around $850^{\circ} \mathrm{C}$, liberating non-crystalline phases, silica and gamma-alumina; ( $\mathrm{Si} / \mathrm{Al}$ ) spinel formation at $\sim 980^{\circ} \mathrm{C}$ and its transformation into mullite $\left(\sim 1150{ }^{\circ} \mathrm{C}\right)$ (Santos et al., 2006).

Chemical, physical and structural transformations of kaolinite during the sintering process have been extensively reviewed in the literature. Mullite crystals are derived from the solid-state decomposition of kaolinite, being the major high-temperature phase (Djangang et al., 2008, Martín-Márquez et al., 2009, Romero et al., 2006, Santos et al., 2006, Torres et al., 2004 and Yamuna et al., 2002). Due to its excellent mechanical, creep, thermal and chemical properties, it has a significant role in the technological features of ceramic materials. The exothermic reaction around $980{ }^{\circ} \mathrm{C}$ detected by DTA is the breakpoint between the noncrystalline phases from metakaolinite decomposition and the crystallization of the phases. The explanation of this peak reaction is one point of disagreement among the published data, principally concerning reactions of non-pure minerals, such as red clays where there are solidstate reactions and reactions in liquid phases dispersed within the ceramic material. According to Percival et al. (1974), the formation of the spinel phase is the only one responsible for the exothermic peak at $980^{\circ} \mathrm{C}$ during the kaolinite heat treatment. Sanz et al. (1988) studied the thermal decomposition of kaolinite and observed that at $980{ }^{\circ} \mathrm{C}$ there are segregation of noncrystalline silica, crystallization of spinel with $\gamma$-alumina structure, and formation of a mullite nucleus with low crystallinity.

Differential thermal analysis (DTA) has been extensively employed to study the kinetics of phase transformation processes and chemical reaction mechanisms during the thermal treatment of clays. The theoretical basis for interpreting DTA results is provided by the Johnson-MehlAvrami-Kolmogorov (JMAK) theory for isothermal treatment, which describes the evolution with time, $t$, of the crystallization fraction, $x$, in terms of the crystal growth rate (Goel et al., 2007).

In general, the structural ceramic products have low added value and are low priced compared to other materials used in building construction. Some industries produce this kind of ceramic using white clay material, which could be used to produce other kinds of ceramic pieces with higher added values than bricks. The knowledge of the raw material properties and its thermal behavior during sintering is important to: (1) the formulation of a mixture of clay, fondant, and sand that can be used to produce new building materials and (2) the production process. In the present work, we characterized and studied the crystallization kinetics, using the DTA technique, of a kaolinitic clear-burning clay used by the ceramic industry to produce an ordinary hollow brick. 
R.A. Silva, S.R. Teixeira, A.E. Souza, D.I. Santos, M. Romero, J.Ma. Rincón, Nucleation kinetics of crystalline phases from a kaolinitic body used in the processing of red ceramics. Applied Clay Science Volume 52, Issues 1-2, April 2011, Pages 165-170; doi:10.1016/j.clay.2011.02.019

\section{Materials and methods}

\subsection{Materials}

The clay sample was a ceramic raw material used to produce bricks and was obtained from the company "Asa Branca" in Teodoro Sampaio-SP, Brazil. This industry use kaolinitic clearburning clay to produce ordinary hollow bricks. After oven drying $\left(100{ }^{\circ} \mathrm{C}, 24 \mathrm{~h}\right)$ the clay material was ground using a knife mill (Marconi - MA880) and analyzed to determine the clay, sand and silt concentrations (pipette method) (Klute, 1986). Its chemical composition was determined by X-ray fluorescence (Model EDX 700, Shimadzu Scientific Instruments).

Differential thermal and thermogravimetric analysis was performed on the clay powders in a TA Instruments thermal analyzer, model SDT Q600 (simultaneous DTA/TG/DSC). The samples were heated in platinum crucibles from room temperature to $1200{ }^{\circ} \mathrm{C}$ at heating rates of $10,20,30,40$ and $50^{\circ} \mathrm{C} / \mathrm{min}$, in flowing air.

The crystalline phases were identified by X-ray diffraction (XRD, Model D/MAX-2100/PC, Rigaku Corporation). To identify the crystalline phases formed at different temperatures, two clay samples were moistened, pressed, fired ( $2 \mathrm{~h}$ each one) at 1000 and at $1190{ }^{\circ} \mathrm{C}$ and analyzed using an X-ray diffractometer (Rigaku). Afterwards, the morphology of the sintered material was determined by scanning electron microscopy (SEM) analysis in a Zeiss DSM-940-A apparatus.

\subsection{Kinetic methods}

The study of the kinetics of crystallization based on the so-called Johnson-Mehl-AvramiKolmogorov (JMAK) model, in amorphous materials by differential scanning calorimetry (DSC) and differential thermal analysis (DTA), has been widely discussed in the literature (Augis and Bennett, 1978, Faleiros et al., 2000, Höland and Beall, 2002, Kissinger, 1956,Ligero et al., 1991, Matusita and Sakka, 1980, Scheel and Fukuda, 2004 and Starink and Zahra, 1997).

Various models have been proposed to determine kinetic parameters for non-isothermal conditions. These include the Kissinger, 1956, Ligero et al., 1991 and Matusita and Sakka, 1980 methods. These models have been used previously in studies of the kinetics of glass crystallization for various glass-ceramic systems (Chen, 2007, Goel et al., 2007, Ray et al., 2007, Reynoso et al., 2003, Romero et al., 2008, Wange et al., 2002 and Wondraczek et al., 2006), in the development of glass-ceramics from wastes (Barbieri et al., 2000, Barbieri et al., 2001, Bernardo et al., 2007, Djangang et al., 2008, Rawlings et al., 2006, Romero and Rincón, 2000, Romero et al., 1999, Romero et al., 2001 and Romero et al., 2008) and among others, to 
R.A. Silva, S.R. Teixeira, A.E. Souza, D.I. Santos, M. Romero, J.Ma. Rincón, Nucleation kinetics of crystalline phases from a kaolinitic body used in the processing of red ceramics. Applied Clay Science Volume 52, Issues 1-2, April 2011, Pages 165-170; doi:10.1016/j.clay.2011.02.019

study the crystallization of mullite from different materials (Campos et al., 2002, Campos et al., 2005, Chen et al., 2004, Monteiro et al., 2004 and Yinnon and Uhlmann, 1983).

For many transformations in the solid state, dependence of crystallization in relation to time is the same, that is, a sigmoidal curve results when the crystallized fraction is plotted as a function of time. Mathematically, the crystallized fraction at time $t$, with the velocity of crystallization constant, is expressed by the JMAK equation as follows (Faleiros et al., 2000,Höland and Beall, 2002, Romero et al., 2006 and Scheel and Fukuda, 2004).

$$
x(t)=1-\exp [n(-k t)]
$$

where $\mathrm{n}$ is the Avrami exponent, which describes the mechanism of crystallization and provides qualitative information on the nature of the processes of nucleation and growth of the crystals, with this parameter varying between 0.5 and 4 . From this by following the methodology of Kissinger (1956) and Ligero et al. (1991); as well as the modified form ofMatusita and Sakka (1980) as shown in Romero et al. (2006), it has been possible to determine the activation energies and the kinetic parameters.

\section{Results and discussion}

Table 1 shows the chemical composition (XRF). The grain size distribution (texture) of the raw material was determined by the pipette method: sand (13.08\%), silt $(30.46 \%)$ and clay $(56.47 \%)$.

Table 1. Chemical composition (XRF) of the clay material (wt.\%).

\begin{tabular}{lllllllllll}
\hline $\mathrm{SiO}_{2}$ & $\mathrm{Al}_{2} \mathrm{O}_{3}$ & $\mathrm{Fe}_{2} \mathrm{O}_{3}$ & $\mathrm{TiO}_{2}$ & $\mathrm{CaO}$ & $\mathrm{MgO}$ & $\mathrm{Na}_{2} \mathrm{O}$ & $\mathrm{K}_{2} \mathrm{O}$ & $\mathrm{MnO}$ & $\mathrm{P}_{2} \mathrm{O}_{5}$ & I. L. \\
\hline 69.74 & 15.97 & 2.06 & 3.11 & 0.03 & 0.19 & $<0.001$ & 0.68 & $<0.001$ & 0.02 & 8.04 \\
\hline
\end{tabular}

Fig. 1 shows X-ray diffraction patterns of the raw material and of the clay fraction $(\mathrm{Mg}$ saturated) oriented on a glass slide. The major minerals identified are kaolinite and quartz. Typically, clays of this region have gibbsite (aluminum hydroxide), hematite and goethite (iron minerals), anatase and rutile (titanium oxides), mica (illite or muscovite, peak at $0.5 \mathrm{~nm}$ ), and montmorillonite (peak at 1.4 changes to $1.8 \mathrm{~nm}$ when glycerol is added to the Mg saturated sample) as minor mineral phases (Teixeira et al., 2001). 
R.A. Silva, S.R. Teixeira, A.E. Souza, D.I. Santos, M. Romero, J.Ma. Rincón, Nucleation kinetics of crystalline phases from a kaolinitic body used in the processing of red ceramics. Applied Clay Science Volume 52, Issues 1-2, April 2011, Pages 165-170; doi:10.1016/j.clay.2011.02.019

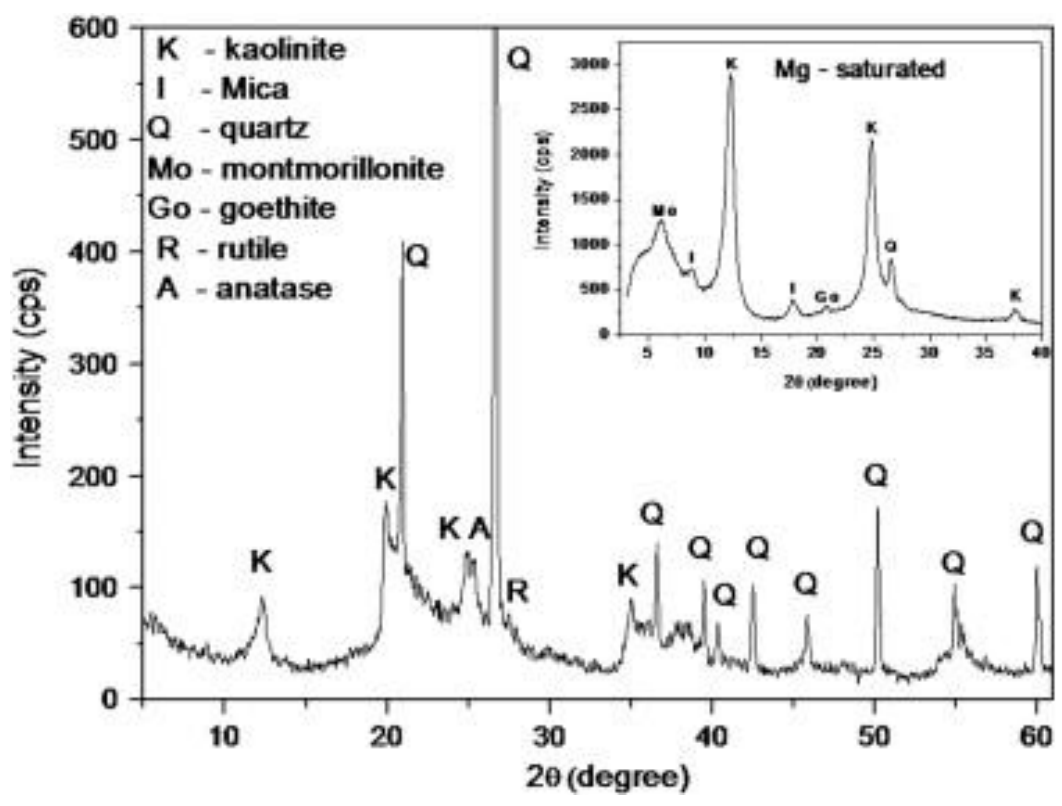

Fig. 1. X-ray diffraction patterns of raw material and (insert) of the clay fraction oriented and $\mathrm{Mg}$ saturated.

Fig. 2 illustrates the differential thermal analysis (DTA) curves for a clay powder at five different heating rates $\left(10{ }^{\circ} \mathrm{C} / \mathrm{min}, 20^{\circ} \mathrm{C} / \mathrm{min}, 30^{\circ} \mathrm{C} / \mathrm{min}, 40^{\circ} \mathrm{C} / \mathrm{min}\right.$ and, $\left.50{ }^{\circ} \mathrm{C} / \mathrm{min}\right)$. As expected, the DTA maximum peak positions shift to higher temperatures as the heating rate increases from 10 to $50{ }^{\circ} \mathrm{C} / \mathrm{min}$. Although these exothermic peaks are generally associated with the crystallization of mullite, the X-ray data (further on) do not show a mullite XRD pattern for the sample sintered at $1000{ }^{\circ} \mathrm{C}$, for $1 \mathrm{~h}$.

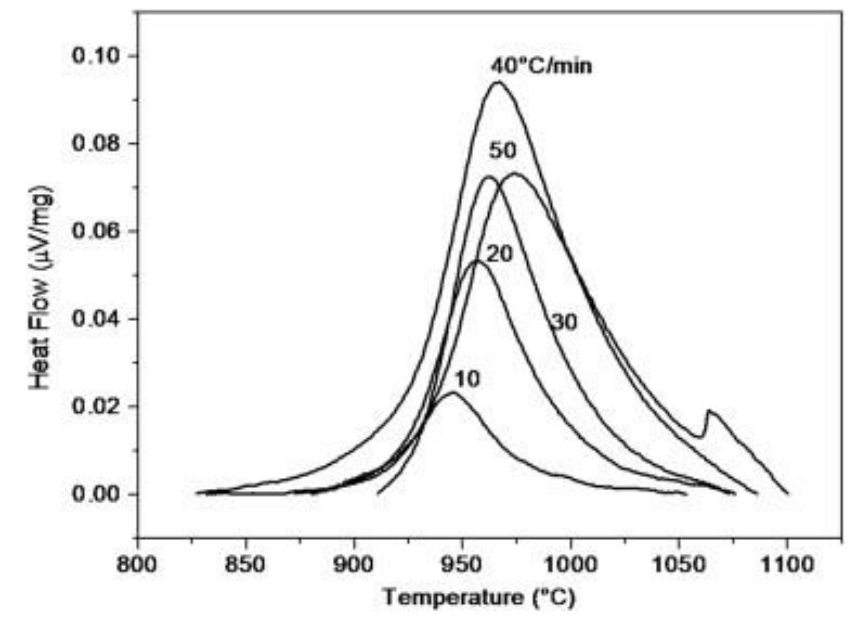

Fig. 2. DTA reaction peaks for the five different heating rates. 
R.A. Silva, S.R. Teixeira, A.E. Souza, D.I. Santos, M. Romero, J.Ma. Rincón, Nucleation kinetics of crystalline phases from a kaolinitic body used in the processing of red ceramics. Applied Clay Science Volume 52, Issues 1-2, April 2011, Pages 165-170; doi:10.1016/j.clay.2011.02.019

Fig. 3 shows the variation of the crystallized fraction $(\mathrm{x})$ with temperature under different heating rates. The crystallized fraction (x) was determined from the DTA curves (Fig. 2) by the ratio between partial peak area at temperature $T\left(A_{T}\right)$ and total peak area $(A)$. These curves show that the crystallization fractions (x) are different at different heating rates, for the same temperature (Chen et al., 2004, Goel et al., 2007 and Romero et al., 2006).

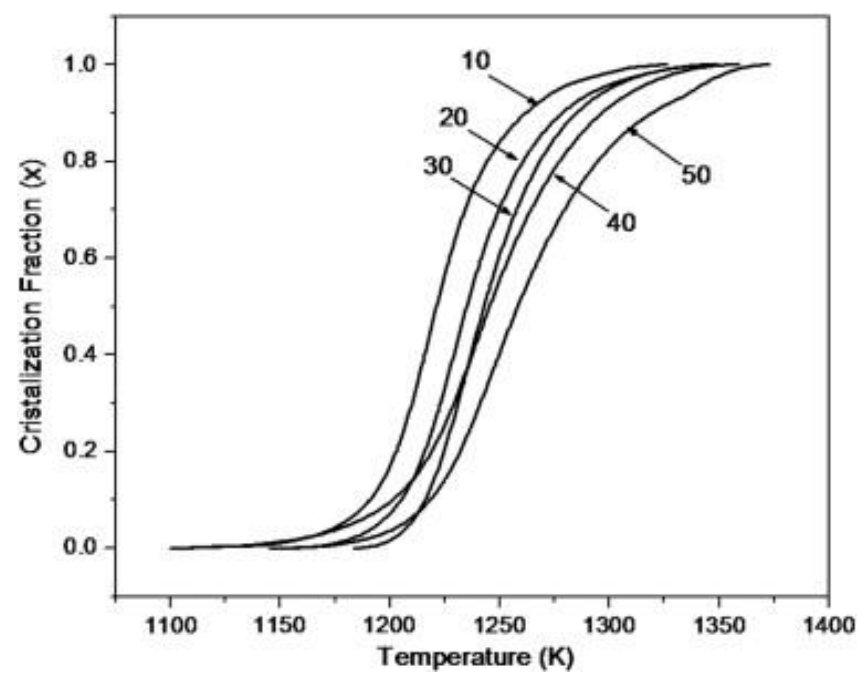

Fig. 3. Variation of the crystallization fraction with temperature under different heating rates.

Fig. 4 shows the plot of $\ln \left(\varphi / T_{\mathrm{p}}{ }^{2}\right)$ versus $1 / \mathrm{T}_{\mathrm{p}}$ according to the Kissinger equation. The activation energy calculated from the slope of the Kissinger plot is $700 \pm 43 \mathrm{~kJ} / \mathrm{mol}$.

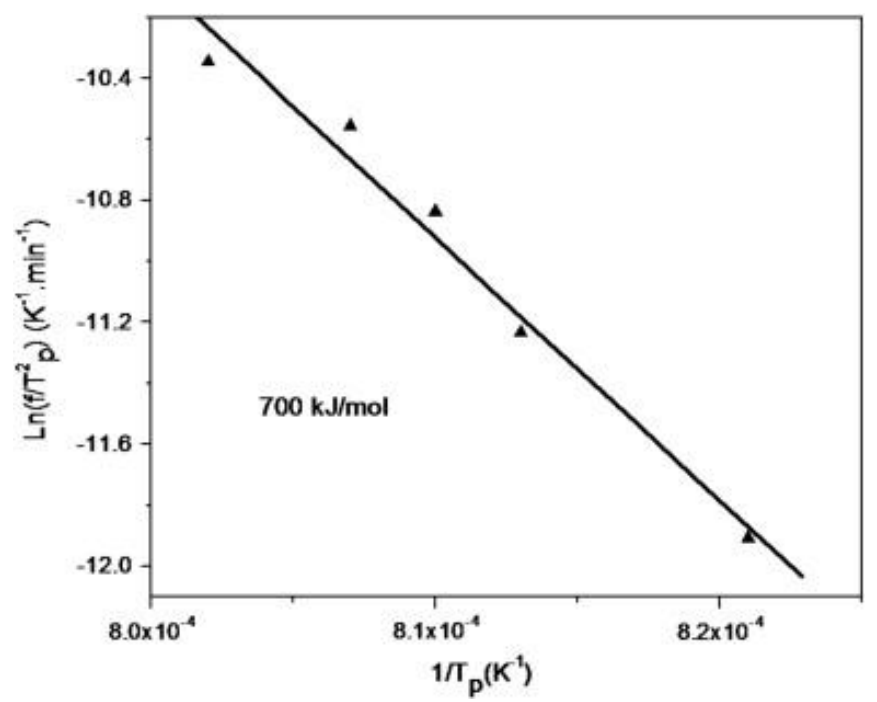

Fig. 4. Plot of $\ln \left(\phi / \mathrm{T}_{\mathrm{p}}^{2}\right)$ vs. $\left(1 / \mathrm{T}_{\mathrm{p}}\right)$ according to the Kissinger equation (Kissinger, 1956). 
R.A. Silva, S.R. Teixeira, A.E. Souza, D.I. Santos, M. Romero, J.Ma. Rincón, Nucleation kinetics of crystalline phases from a kaolinitic body used in the processing of red ceramics. Applied Clay Science Volume 52, Issues 1-2, April 2011, Pages 165-170; doi:10.1016/j.clay.2011.02.019

Fig. 5 shows the plot of $\ln (\mathrm{dx} / \mathrm{dt})$ versus $1 / \mathrm{T}$ for the same value of crystallized fraction $(\mathrm{x})$ according to the Ligero method (Ligero et al., 1991). In this method, only the first three heating rates were used, because for 40 and $50{ }^{\circ} \mathrm{C} / \mathrm{min}$ there is a deviation from linearity adjustment relative to the other heating rates. Table 2 shows the activation energies (E) for different crystallized fractions calculated from the slopes of the lines. For these three heating rates, the $\ln (\mathrm{dx} / \mathrm{dt})$ is linear with $1 / \mathrm{T}$, in the range $\mathrm{x}=0.1$ to $0.3(\mathrm{r}=0.999)$, and the average activation energy is $721 \pm 32 \mathrm{~kJ} / \mathrm{mol}$. These results show that the activation energy decreases with the crystallization fraction $(\mathrm{x})$.

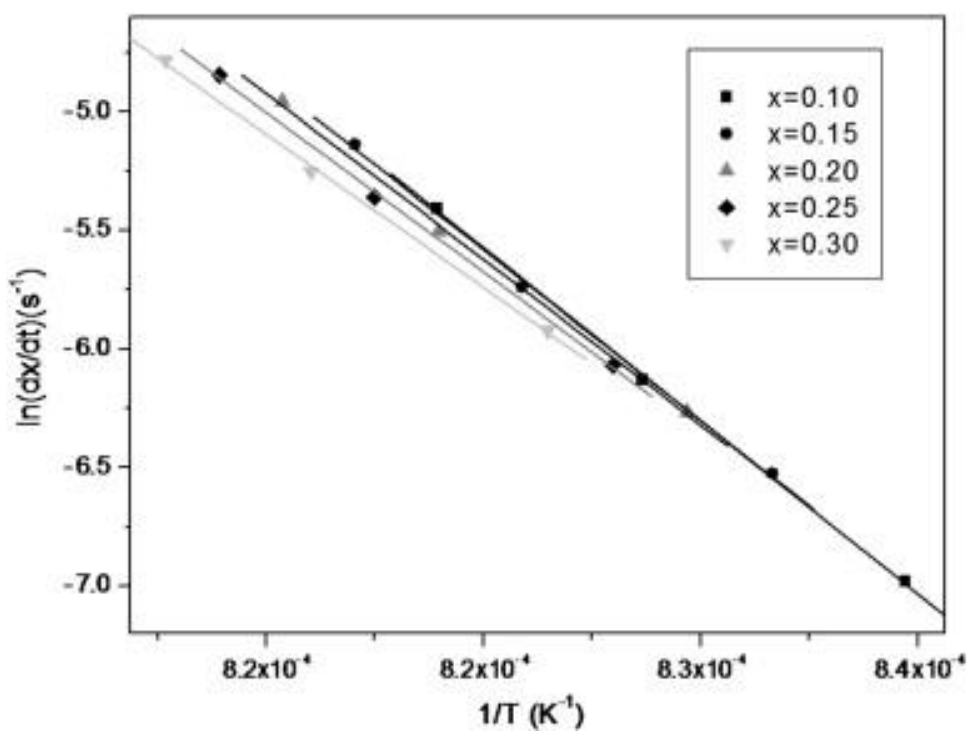

Fig. 5. Plot of $\ln (\mathrm{dx} / \mathrm{dt})$ vs. 1/T (Ligero method) indicating the fraction of crystallization (x).

Table 2. Activation energy values, E, for different fractions of crystallization (x).

\begin{tabular}{ccc}
\hline $\mathrm{x}$ & $\mathrm{r}$ (correlation coefficient) & $\mathrm{E}(\mathrm{kJ} / \mathrm{mol} \cdot \mathrm{K})$ \\
\hline 0.10 & 0.9997 & 758 \\
0.15 & 0.9993 & 748 \\
0.20 & 0.9992 & 727 \\
0.25 & 0.9995 & 700 \\
0.30 & 0.9994 & 670 \\
\hline
\end{tabular}

The crystallization kinetics of mullite from clays can be discussed in terms of two stages. In the first step of the process, small mullite crystals are formed or nucleated from clay relicts and 
R.A. Silva, S.R. Teixeira, A.E. Souza, D.I. Santos, M. Romero, J.Ma. Rincón, Nucleation kinetics of crystalline phases from a kaolinitic body used in the processing of red ceramics. Applied Clay Science Volume 52, Issues 1-2, April 2011, Pages 165-170; doi:10.1016/j.clay.2011.02.019

in the second stage, mullite crystals grow. Consequently, the crystallization process takes place not only with a single value of activation energy and it would be more accurate to define a narrow activation energy $E(\alpha)$, which presents the activation energy at a stage when the crystallized volume fraction is $\alpha$. The activation energy consists of two components: $E_{\mathrm{n}}$ and $E_{\mathrm{g}}$, which are the nucleation and growth contribution to the activation energy, respectively (Yinnon and Uhlmann, 1983). Taking into account the process described above, our data indicates that, at early stages of crystallization, the process is probably dominated by the nucleation of small mullite crystals whereas for the final stage, the crystallization is likely dominated by the growth process. A decrease in activation energy $E(\alpha)$ with crystallized fraction ( Table 2) indicates that once the nuclei are formed, the growth of mullite crystals is promoted while the nucleation of new crystals is inhibited.

Usually, the crystallization peak observed in kaolinitic clays is attributed to mullite formation and its activation energy, found in the literature, ranges from 526 to $1182 \mathrm{~kJ} / \mathrm{mol}$ for different raw materials (kaolin for ceramics, raw material for porcelain, gels with and without seed) with different chemical compositions (Campos et al., 2002, Campos et al., 2005, Chen et al., 2004, Djangang et al., 2008, Monteiro et al., 2004 and Romero et al., 2006). Campos et al. (2002) obtained an activation energy of the order of $730 \mathrm{~kJ} / \mathrm{mol}$ for the crystallization of mullite from diphasic gels. Romero et al. (2006) studied the kinetics of mullite formation in a mixture of kaolinitic clay (50\%), feldspar (40\%) and sand (10\%) and found an activation energy of $622 \mathrm{~kJ} / \mathrm{mol}$. Of the articles mentioned above Romero et al. (2006) have the activation energy closer to the value obtained in this work. Although the concentration of fluxes and stabilizers $(\mathrm{Na}, \mathrm{K}, \mathrm{Ca}$ and $\mathrm{Mg}$ ) in the mixture is greater than in our sample its peak of crystallization (DTA) occurs at a slightly higher temperature. The differences in the chemical compositions of the raw materials where some metal oxides (nucleating agents, stabilizers and fluxes) usually influence the parameters and process of nucleation and crystallization will result in different activation energies and mechanisms of reaction as is observed in the literature.

Using the average activation energy the values of $\ln \left[k_{0} f(x)\right]$ were calculated. Fig. 6 shows the variation of $\ln \left[k_{0} f(x)\right]$ in relation to the fraction of crystallization obtained for a heating rate of $30{ }^{\circ} \mathrm{C} / \mathrm{min}$. Similar curves were obtained for other heating rates used in this work. 


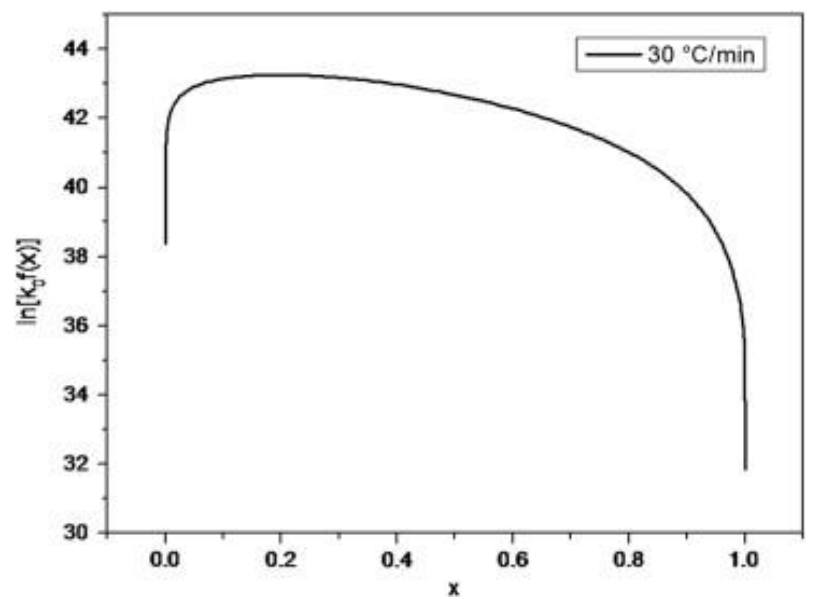

Fig. 6. Curve of $\ln \left[\mathrm{k}_{\mathrm{o}} \mathrm{f}(\mathrm{x})\right]$ vs. the fraction of crystallization, $\mathrm{x}$, using a heating rate of $30^{\circ} \mathrm{C} / \mathrm{min}$.

The Avrami parameter, $\mathrm{n}$, was determined selecting values of fraction of crystallization $x_{1}$ and $x_{2}$ of the extremes of the curve in Fig. 6 , that satisfy the condition $\ln \left[k_{0} f\left(x_{1}\right)\right]=\ln \left[k_{0} f\left(x_{2}\right)\right]$.Table 3 shows the values of $\mathrm{n}$ obtained for different heating rates (Ligero et al., 1991).

Table 3. Avrami parameter (n) values and $\mathrm{t}_{0.75} / \mathrm{t}_{0.25}$ ratio.

\begin{tabular}{ccc}
\hline Heating rate $\left({ }^{\circ} \mathrm{C} / \mathrm{min}\right)$ & $\mathrm{n}$ & $\mathrm{t}_{0.75} / \mathrm{t}_{0.25}$ \\
\hline 10 & 1.20 & 1.31 \\
20 & 1.15 & 1.53 \\
30 & 1.15 & 1.78 \\
Mean & 1.17 & 1.54 \\
\hline
\end{tabular}

The morphology of crystal growth can be indicated taking the relation of the times of transformation for two corresponding fractions of crystallization. One convenient representative index is the relation of time for the transformation of 75 and $25 \%$ such that $2.20 \leq \mathrm{t}_{0.75} / \mathrm{t}_{0.25} \leq 4.82$ describes uni-dimensional growth (needles), $1.69 \leq \mathrm{t}_{0.75} / \mathrm{t}_{0.25} \leq 2.20$ twodimensional growth (plates), and $1.48 \leq \mathrm{t}_{0.75} / \mathrm{t}_{0.25} \leq 1.69$ three-dimensional growth (polyhedral). The results shown in Table 3 indicate that the morphology of crystal growth observed in the DTA data varies with heating rate between volumetric and planar (Campos et al., 2002).

Utilizing the Matusita equation (Matusita and Sakka, 1980) and the values of $n$ and $E$ obtained with the Ligero method, the calculated parameter $\mathrm{m}(1.16)$ is close to 1 . These values and the ratio $t_{0.75} / t_{0.25}$, suggest a three-dimensional crystal growth with polyhedron-like 
R.A. Silva, S.R. Teixeira, A.E. Souza, D.I. Santos, M. Romero, J.Ma. Rincón, Nucleation kinetics of crystalline phases from a kaolinitic body used in the processing of red ceramics. Applied Clay Science Volume 52, Issues 1-2, April 2011, Pages 165-170; doi:10.1016/j.clay.2011.02.019

morphology. These results also indicate that the surface nucleation is the dominant mechanism crystallization and the crystal growth is controlled by interface reaction.

Fig. 7 shows the X-ray diffractograms of two samples treated at 1000 and $1190{ }^{\circ} \mathrm{C}$, for $2 \mathrm{~h}$. Although the identification of mullite $\left(3 \mathrm{Al}_{2} \mathrm{O}_{3} \cdot 2 \mathrm{SiO}_{2}\right)$ was expected in the sample sintered at $1000{ }^{\circ} \mathrm{C}$, as indicated by the exothermic peak (DTA) of crystallization at $980{ }^{\circ} \mathrm{C}$, it was only identified in the sample treated at $1190{ }^{\circ} \mathrm{C}$. At $1000{ }^{\circ} \mathrm{C}$, peaks of alpha-quartz were identified (PDF 05-490) as major phase, along with some peaks of low intensity and a halo close to $30^{\circ}$, characteristic of the presence of amorphous phases. A broad peak near $46^{\circ}$ ( 2 theta) indicating the formation of Al-Si spinel phase is also noted (Fig. 8) (Chakraborty, 2008). The high concentration of silt and sand (with predominance of quartz) is compatible with the chemical analysis of clay, that is, high concentration of silica. The low concentration of alumina implies the limitation of the amount of mullite that will be crystallized. Also, the formation of mullite increases with heating rate from 1050 to $1300{ }^{\circ} \mathrm{C}$, as shown by Chen et al. (2004). In that work, they mention that when heated to $950{ }^{\circ} \mathrm{C}$ the $\mathrm{SiO}_{4}$ groups combine with the $\mathrm{AlO}_{6}$ group to form the spinel phase $\mathrm{Al}-\mathrm{Si}$ with a structure of short-range order. This phase appears at $920{ }^{\circ} \mathrm{C}$ and persists up to $1150{ }^{\circ} \mathrm{C}$. Sanz et al. (1988) also observed that at $980{ }^{\circ} \mathrm{C}$ there are segregation of non-crystalline silica, crystallization of spinel with $\gamma$-alumina structure, and the formation of a mullite nucleus with low crystallinity. Therefore, our data are in agreement with these results, i.e., they show that the exothermic DTA peak at $980{ }^{\circ} \mathrm{C}$ is associated with the formation of spinel phase $\mathrm{Al}-\mathrm{Si}$ and nucleation of mullite with a structure of short-range order.

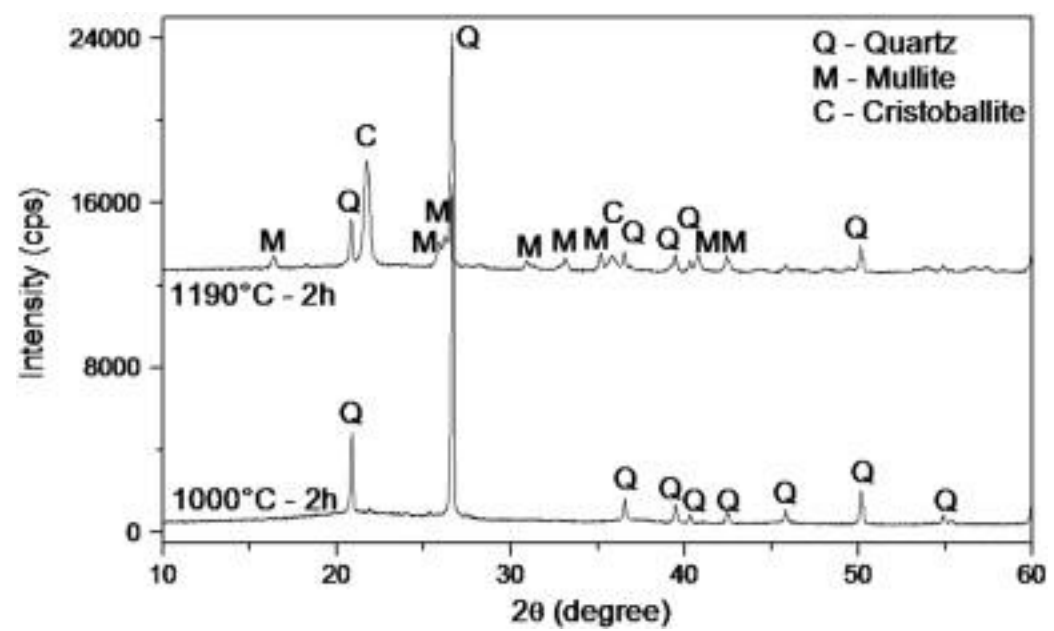

Fig. 7. X-ray diffractogram of clay treated at $1000^{\circ} \mathrm{C}$ and $1190^{\circ} \mathrm{C}$ for $2 \mathrm{~h}$, with a heating rate of 20 ${ }^{\circ} \mathrm{C} / \mathrm{min}$ 
R.A. Silva, S.R. Teixeira, A.E. Souza, D.I. Santos, M. Romero, J.Ma. Rincón, Nucleation kinetics of crystalline phases from a kaolinitic body used in the processing of red ceramics. Applied Clay Science Volume 52, Issues 1-2, April 2011, Pages 165-170; doi:10.1016/j.clay.2011.02.019

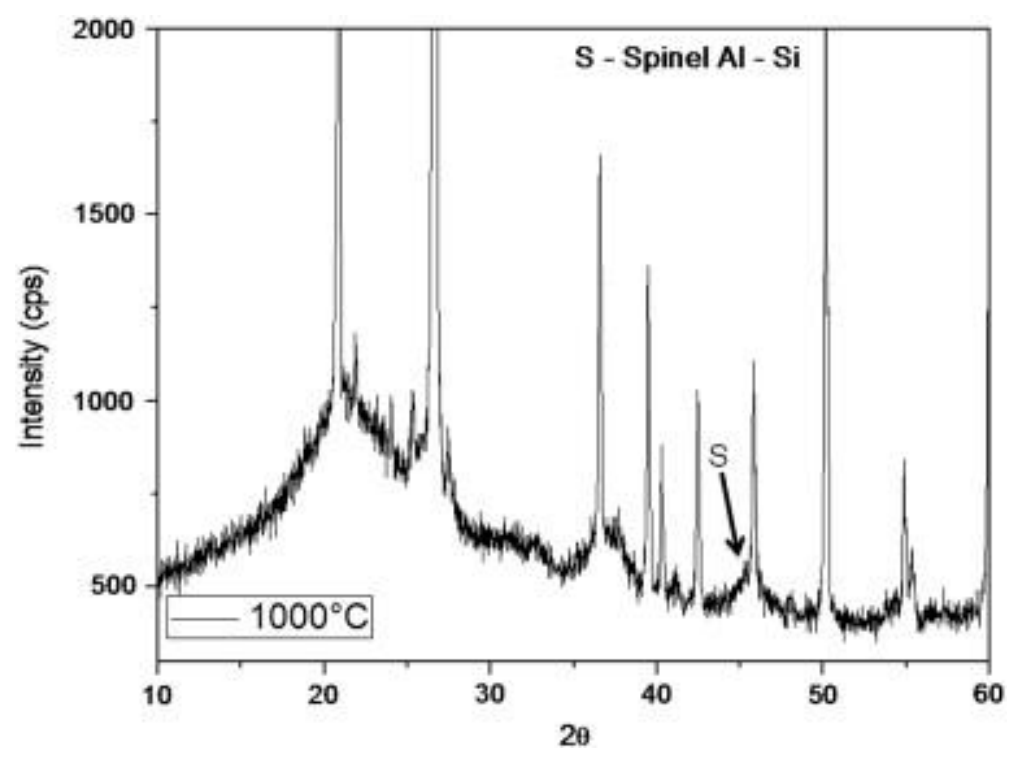

Fig. 8. X-ray diffraction pattern showing the amorphous and $\mathrm{Si}-\mathrm{Al}$ spinel phases to the sample treated at $1000{ }^{\circ} \mathrm{C}$ for $2 \mathrm{~h}$.

Fig. 9 shows SEM images of the ceramic bodies after firing at $1000{ }^{\circ} \mathrm{C}$ (a) and $1190{ }^{\circ} \mathrm{C}(\mathrm{b})$. The body fired at lower temperature (Fig. 9a) shows a typical under-firing ceramic microstructure with high-interconnected porosity. The microstructure of the sample fired at $1190{ }^{\circ} \mathrm{C}$ (Fig. 9b) is denser than that fired at $1000^{\circ} \mathrm{C}$ due to the liquid phase formed from the fluxing agents. Above $1000{ }^{\circ} \mathrm{C}$ the two high temperature stable phases (mullite and cristobalite) from fired kaolinite are developed. The presence of mineralizing (fluxing agents) accelerates the nucleation and crystal growth of these phases as well as the formation of glassy phase which promotes sintering and densification of the ceramic material. The XRD data show the formation of these two phases for the sample treated to $1190{ }^{\circ} \mathrm{C}$ and the image of SEM shows that the sample is denser for this sintering temperature. 
R.A. Silva, S.R. Teixeira, A.E. Souza, D.I. Santos, M. Romero, J.Ma. Rincón, Nucleation kinetics of crystalline phases from a kaolinitic body used in the processing of red ceramics. Applied Clay Science Volume 52, Issues 1-2, April 2011, Pages 165-170; doi:10.1016/j.clay.2011.02.019

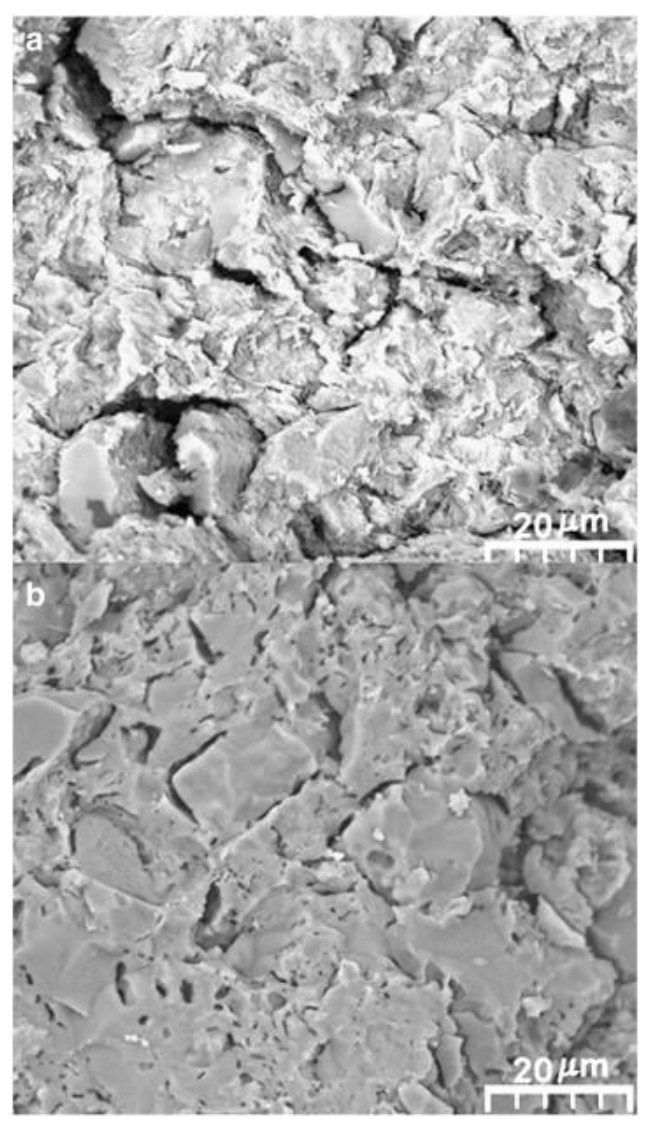

Fig. 9. SEM images (1000x) of clay samples treated at $1000^{\circ} \mathrm{C}(1)$ and $1190{ }^{\circ} \mathrm{C}(2)$ for $2 \mathrm{~h}$.

\section{Conclusions}

The results suggest a three-dimensional crystal growth of mullite with polyhedron-like morphology and that surface nucleation is the dominant mechanism of crystallization. The exothermic DTA peak at $980{ }^{\circ} \mathrm{C}$ is associated with the formation of spinel phase $\mathrm{Al}-\mathrm{Si}$ with a structure of short-range order and nucleation of mullite. The crystal growth is controlled by interface reactions with apparent activation energies of $721 \pm 32 \mathrm{~kJ} / \mathrm{mol}$ (Ligero method) and $700 \pm 43 \mathrm{~kJ} / \mathrm{mol}$ (Kissinger method). XRD data show quartz, spinel Al-Si and "amorphous" (short-range order) phase at $1000{ }^{\circ} \mathrm{C}$ and, quartz, cristobalite and orthorhombic mullite at $1190{ }^{\circ} \mathrm{C}$. SEM images show a denser material to the sample sintered at $1190{ }^{\circ} \mathrm{C}$ due to liquid phase and mullite crystallization. 
R.A. Silva, S.R. Teixeira, A.E. Souza, D.I. Santos, M. Romero, J.Ma. Rincón, Nucleation kinetics of crystalline phases from a kaolinitic body used in the processing of red ceramics. Applied Clay Science Volume 52, Issues 1-2, April 2011, Pages 165-170; doi:10.1016/j.clay.2011.02.019

\section{Acknowledgments}

The authors thank FUNDUNESP and FAPESP (2008/04368-4) for financial support of this work. We also are grateful to PROPE/UNESP/SANTANDER for Dr. Teixeira's post-doc scholarship in Madrid.

\section{References}

1. Augis and Bennett, 1978 J.A. Augis, J.E. Bennett Calculation of the Avrami parameters for heterogeneous solid-state reactions using a modification of the Kissinger method J. Therm. Anal., 13 (1978), pp. 283-292

2. Barbieri et al., 2000 A.M.F. Barbieri, I. Lancelloti, C. Leonelli, J.Ma. Rincón, M. Romero Crystallization of $\left(\mathrm{Na}_{2} \mathrm{O}-\mathrm{MgO}\right)-\mathrm{CaO}-\mathrm{Al}_{2} \mathrm{O}_{3}-\mathrm{SiO}_{2}$ glassy systems formulated from waste products J. Am. Ceram. Soc., 83 (2000), pp. 2515-2520

3. Barbieri et al., 2001 L. Barbieri, I. Lancelloti, T. Manfredini, G.C. Pellacani, J.Ma. Rincón, M. Romero Nucleation and crystallization of new glasses obtained from fly ash originating from thermal power plants J. Am. Ceram. Soc., 84 (2001), pp. 1851-1858

4. Bernardo et al., 2007 E. Bernardo, R. Castellano, S. Hreglich Sintered glass-ceramics from mixtures of wastes Ceram. Int., 33 (2007), pp. 27-33

5. Campos et al., 2002 A.L. Campos, N.T. Silva, F.C.L. Melo, M.A.S. Oliveira, G.P. Thim. Mullite Crystallization kinetics of orthorrombic mullite from diphasic gels J. NonCryst. Sol., 304 (2002), pp. 19-24

6. Campos et al., 2005 A.L. Campos, E.Y. Kawachi, T.C. Oliveira, G.P. Thim. Mullite crystallization mechanism obtained from kinetic parameters determination for seeded and non-seeded gel Mater. Sci. Eng. B, 122 (2005), pp. 169-173

7. Chakraborty, 2008 A.K. Chakraborty Si-incorporated alumina phases formed out of diphasic mullite gels J. Mater. Sci., 43 (2008), pp. 5313-5324

8. Chen, 2007 G.H. Chen Effect of replacement of $\mathrm{MgO}$ by $\mathrm{CaO}$ on sintering crystallization and properties of $\mathrm{MgO}-\mathrm{Al}_{2} \mathrm{O}_{3}-\mathrm{SiO}_{2}$ system glass-ceramics J. Mater. Sci., 42 (2007), pp. 7239-7244

9. Chen et al., 2004 Y.-F. Chen, M.-C. Wang, M.-H. Hon Phase transformation and growth of mullite in kaolin ceramics J. Eur. Ceram. Soc., 24 (2004), pp. 2389-2397 
R.A. Silva, S.R. Teixeira, A.E. Souza, D.I. Santos, M. Romero, J.Ma. Rincón, Nucleation kinetics of crystalline phases from a kaolinitic body used in the processing of red ceramics. Applied Clay Science Volume 52, Issues 1-2, April 2011, Pages 165-170; doi:10.1016/j.clay.2011.02.019

10. Djangang et al., 2008 C.N. Djangang, A. Elimbi, U.C. Melo, G.L. Lecomte, C. Nkoumbou, J. Soro, J.P. Bonnet, P. Blanchart, D. Njopwouo Sintering of clay-chamote ceramic composites for refractory bricks Ceram. Int., 34 (2008), pp. 1207-1213

11. Faleiros et al., 2000 A.C. Faleiros, T.N. Rabelo, G.P. Thim, M.A.S. Oliveira Kinetics of phase change Mater. Res., 3 (2000), pp. 51-60

12. Goel et al., 2007 A. Goel, E.R. Shaaban, F.C.L. Melo, M.J. Ribeiro, J.M.F. Ferreira Non-isothermal crystallization kinetic studies on $\mathrm{MgO}-\mathrm{Al}_{2} \mathrm{O}_{3}-\mathrm{TiO}_{2}$ glass J. Non-Cryst. Sol., 353 (2007), pp. 2383-2391

13. Höland and Beall, 2002 W. Höland, G. Beall Glass-Ceramic Technology The American Ceramic Society, Westerville, OH (2002)

14. Kissinger, 1956 H.E. Kissinger Variation of peak temperature with heating rate in differential thermal analysis J. Res. Natl Bur. Stand., 57 (1956), pp. 217-221

15. Klute, 1986 A. Klute Methods of Soil Analysis: Physical and Mineralogical Methods Part 1 Soil Science Society of America Book Series, No. 9 (Part 1) Agronomy Series, Madison, Wisconsin, USA (Second Edition) (1986)

16. Ligero et al., 1991 R.A. Ligero, J. Vázques, P. Villares, R. Jiménez-Garay A study of the crystallization kinetics of some Cu-As-Te glasses J. Mater. Sci., 26 (1991), pp. 211215

17. Martín-Márquez et al., 2009 J. Martín-Márquez, A.G. De la Torre, M.A.G. Aranda, J.Ma. Rincón, M. Romero Evolution with temperature of crystalline and amorphous phases in porcelain stoneware J. Am. Ceram. Soc., 92 (2009), pp. 229-234

18. Matusita and Sakka, 1980 K. Matusita, S. Sakka Kinetic-study on crystallization of glass by differential thermal-analysis: criterion on application of Kissinger plot J. Non-Cryst. Sol., 38-39 (1980), pp. 741-746

19. Monteiro et al., 2004 R.R. Monteiro, A.C.S. Sabioni, G.M. Costa Preparação de mulita a partir do mineral topázio [Mullite preparation from topaz mineral] Cerâmica, 50 (2004), pp. 318-323

20. Okada, 2008 K. Okada Activation energy of mullitization from various starting materials J. Eur. Ceram. Soc., 28 (2008), pp. 377-382 
R.A. Silva, S.R. Teixeira, A.E. Souza, D.I. Santos, M. Romero, J.Ma. Rincón, Nucleation kinetics of crystalline phases from a kaolinitic body used in the processing of red ceramics. Applied Clay Science Volume 52, Issues 1-2, April 2011, Pages 165-170; doi:10.1016/j.clay.2011.02.019

21. Percival et al., 1974 H.J. Percival, J.F. Duncan, P.K. Foster Interpretation of the kaolinite-mullite reaction sequence from infrared absorption spectra J. Am. Ceram. Soc., 57 (1974), pp. 57-61

22. Rawlings et al., 2006 R.D. Rawlings, J.P. Wu, A.R. Boccaccini Glass-ceramics: their production from wastes - a review J. Mater. Sci., 41 (2006), pp. 733-761

23. Ray et al., 2007 C.S. Ray, T. Zhang, S.T. Reis, R.K. Brow Determining kinetic parameters for isothermal crystallization of glasses J. Am. Ceram. Soc., 90 (2007), pp. 769-773

24. Reynoso et al., 2003 V.C.S. Reynoso, K. Yukimitu, T. Nagami, C.L. Carvalho, J.C.S. Moraes, E.B. Araújo Crystallization kinetics in phosphate sodium-based glass studied by DSC technique J. Phys. Chem. Sol., 64 (2003), pp. 27-30

25. Romero and Rincón, 2000 M. Romero, J.Ma. Rincón El proceso de vitrificación/cristalización controlada aplicado al reciclado de residuos industriales inorgánicos Bol. Soc. Esp. Ceram. Vidrio, 39 (2000), pp. 155-163

26. Romero et al., 1999 M. Romero, R.D. Rawlings, J.Ma. Rincón Development of a new glass-ceramic by means of controlled vitrification and crystallization of inorganic wastes from urban incineration J. Eur. Ceram. Soc., 19 (1999), pp. 2049-2058

27. Romero et al., 2001 M. Romero, J.Ma. Rincón, R.D. Rawlings, A.R. Boccacinni Use of vitrified urban incinerator waste as raw material for production of sintered glassceramics Mater. Res. Bull., 36 (2001), pp. 383-395

28. Romero et al., 2006 M. Romero, J. Martin-Márquez, J.Ma. Rincón Kinetic of mullite formation from a porcelain stoneware body for tiles production J. Eur. Ceram. Soc., 26 (2006), pp. 1647-1652

29. Romero et al., 2008 M. Romero, J. Kovacova, J.Ma. Rincón Effect of particle size on kinetic crystallization of an iron-rich glass J. Mater. Sci., 43 (2008), pp. 4135-4142

30. Santos et al., 2006 H.S. Santos, P. Kiyohara, A.C.V. Coelho, P.S. Santos Electron microscopy study of the transformations during firing of Brazilian high-alumina clays Cerâmica, 52 (2006), pp. 125-137 
R.A. Silva, S.R. Teixeira, A.E. Souza, D.I. Santos, M. Romero, J.Ma. Rincón, Nucleation kinetics of crystalline phases from a kaolinitic body used in the processing of red ceramics. Applied Clay Science Volume 52, Issues 1-2, April 2011, Pages 165-170; doi:10.1016/j.clay.2011.02.019

31. Sanz et al., 1988 J. Sanz, A. Madani, J.M. Serratosa, J.S. Moya, S. Aza Aluminum-27 and Silicon-29 magic-angle spinning nuclear magnetic resonance study of the kaolinite-mullite transformation J. Am. Ceram. Soc., 71 (1988), pp. 418-421

32. Scheel and Fukuda, 2004 H. Scheel, T. Fukuda Crystal Growth Technology John Wiley \& Sons Ltd, Chichester (2004)

33. Starink and Zahra, 1997 M.J. Starink, A.M. Zahra An analysis method for nucleation and growth controlled reactions at constant heating rate Thermochim. Acta, 292 (1997), pp. 159-168

34. Teixeira et al., 2001 S.R. Teixeira, S.A. Souza, C.A.I. Moura Mineralogycal characterization of clays used in the structural ceramic industry in west of S. Paulo state, Brazil Cerâmica, 47 (2001), pp. 204-207

35. Teixeira et al., 2004 S.R. Teixeira, S.A. Souza, M.A.L. Nobre Physical and mechanical properties of ceramics from clays of the west region of São Paulo state-Brazil Cerâmica, 50 (2004), pp. 268-273

36. Torres et al., 2004 P. Torres, H.R. Fernades, S. Agathopoulos, D.U. Tulyaganov, J.M.F. Ferreira Incorporation of granite cutting sludge in industrial porcelain tile formulations J. Eur. Ceram. Soc., 24 (2004), pp. 3177-3185

37. Traoré et al., 2006 K. Traoré, F. Gridi-Bennadji, P. Blanchart Significance of kinetic theories on the recrystallization of kaolinite Thermochim. Acta, 451 (2006), pp. 99-104

38. Wange et al., 2002 P. Wange, T. Höche, C. Rüssel, J.D. Schnapp Microstructureproperty relationship in high-strength $\mathrm{MgO}-\mathrm{Al}_{2} \mathrm{O}_{3}-\mathrm{SiO}_{2}-\mathrm{TiO}_{2}$ glass-ceramics J. NonCryst. Sol., 298 (2002), pp. 137-145

39. Wondraczek et al., 2006 L. Wondraczek, J. Deubener, S.T. Misture, R. Knitter Crystallization kinetics of lithium orthosilicate glasses J. Am. Ceram. Soc., 89 (2006), pp. $1342-1346$

40. Yamuna et al., 2002 A. Yamuna, S. Devanarayanan, M. Lalithambika Phase-pure mullite from kaolinite J. Eur. Ceram. Soc., 85 (2002), pp. 1409-1413 
R.A. Silva, S.R. Teixeira, A.E. Souza, D.I. Santos, M. Romero, J.Ma. Rincón, Nucleation kinetics of crystalline phases from a kaolinitic body used in the processing of red ceramics. Applied Clay Science Volume 52, Issues 1-2, April 2011, Pages 165-170; doi:10.1016/j.clay.2011.02.019

41. Yinnon and Uhlmann, 1983 H. Yinnon, D.R. Uhlmann Applications of thermoanalytical techniques to the study of crystallization kinetics in glass-forming liquids, part I: theory J. Non-Cryst. Sol., 54 (1983), pp. 253-275 